\title{
Blues z rimskega zidu
}

\section{W. H. Auden}

»Nad barjem je veter in moker je zrak, uši imam v tuniki, v nosu prehlad.

Z neba štropotajo nalivi dežja, vojak sem na zidu, ne vem sploh, zakaj.

Po sivem kaménju se plazi megla, dekle imam v Tungriji, jaz pa spim sam.

Prerad se ji Avel pred hišo smoli, pri njem mi ni všeč ne vedenje ne fris.

In Pizon, ki ribo časti kot kristjan, poljube najrajši bi ukiniti dal.

Njen prstan, darilo, sem že zaigral; le njo bi spet rad in zaslužen denar.

Ko v pokoj bom šel, slep na eno oko, ne bom niti mignil, le gledal v nebo.« 